\title{
The susceptibility to lysozyme of $\beta$-lactamase- producing and non-producing derivatives of Staphylococcus aureus strain 1030
}

\author{
M. MILLAR
}

The Old Medical School, Thoresby Place, Leeds LS2 9NL

Summary. The killing of Staphylococcus aureus strain 1030 and derived variants of it by lysozyme increased with increased lysozyme concentrations or decreased concentrations of sodium chloride. $\beta$-Lactamase-producing and non-producing derivatives of strain 1030 were constructed. The former were less susceptible to lysozyme. Induction of $\beta$-lactamase synthesis with 2-2'carboxyphenyl-benzoyl-6penicillanic acid increased the resistance of producer strains to lysozyme. These results are discussed in relation to the spread of $\beta$-lactamase-producing strains of $S$. aureus.

\section{Introduction}

In a previous study (Millar and Lacey, 1984), it was suggested that lysozyme from tears selects for $\beta$-lactamase production in Staphylococcus aureus. Staphylococcal $\beta$-lactamase may be bound to the cell membrane (Neilsen and Lampen, 1982) or ionically associated with the cell wall (Coles and Gross, 1967). It contains a high concentration of polar amino-acids, particularly lysine (Ambler and Meadway, 1969), and has an iso-electric point of 8.9 (Richmond, 1975).

Lysozyme is also a cationic protein ( $p$ I 11.0) present in the primary and secondary granules of human neutrophils (Leffell and Spitznagel, 1972; Bretz and Baggiolini, 1974) and also, in high concentration, in tears and, therefore, in nasal secretions. Lysozyme is a muramidase, its action on the peptidoglycan of Micrococcus lysodeikticus resulting in cell lysis (Davies et al., 1969). The cell wall of $S$. aureus is resistant to the muramidase activity of lysozyme (Brumfitt et al., 1958; Mandelstam and Strominger, 1961; Morse, 1965; Thorne et al., 1976) but several authors have shown that lysozyme can degrade the cell wall of $S$. aureus, possibly by activating autolytic wall enzymes (Kern et al., 1951; Mitchell and Moyle, 1957; Wecke et al., 1982). Lysozyme has also been shown to inhibit bacterial growth (Iacono et al., 1980) and, in certain conditions, to cause bacterial aggregation (Golub et al., 1985). In this study, the killing of S. aureus by lysozyme has been investigated and the hypoth-

Received 20 Feb. 1986; revised version accepted 25 Jun. 1986. esis that lysozyme, derived from tears, selects for $\beta$ lactamase production by $S$. aureus has been examined.

\section{Materials and methods}

\section{Bacterial strains}

A rifampicin-resistant $\left(\mathrm{Rf}^{\mathrm{R}}\right)$ derivative of $S$. aureus strain 1030 (Novick, 1967) was selected by growth of strain 1030 on nutrient-agar plates containing rifampicin $50 \mathrm{mg} / \mathrm{L}$. This was used to construct two pairs of strains, each pair being isogenic except for the characteristic of $\beta$-lactamase production, by the following method. $S$. aureus strain 13136 (Jevons, 1961), which carries a plasmid coding for resistance to cadmium ions and highlevel $\beta$-lactamase production, was treated with $\mathrm{N}$-ethyl$\mathrm{N}^{\prime}$-nitro $\mathrm{N}$-nitrosoguanidine to produce a $\beta$-lactamasenegative $(\beta 1 \mathrm{a}-)$ derivative that was cadmium resistant $\left(\mathrm{Cd}^{\mathrm{R}}\right)$. Mitomycin C (Lacey, 1971) was used to induce phage lysis of these two strains. The lysate was filtered through an $0 \cdot 2-\mu \mathrm{m}$ filter and tested for sterility. Cadmium resistance was transferred to the $\mathbf{R f}^{\mathbf{R}}$ variant of strain 1030 by transduction by the method of Dyke et al. (1970), such that two strains were produced differing only with respect to $\beta$-lactamase synthesis (strains 1030 $\mathrm{Rf}^{\mathrm{R}}, \mathrm{Cd}^{\mathrm{R}}, \beta \mathrm{la}+$ and $\left.1030 \mathrm{Rf}^{\mathrm{R}}, \mathrm{Cd}^{\mathrm{R}}, \beta \mathrm{la}-\right)$. These two strains were used in subsequent experiments.

Two further strains were derived from them. Cadmium sensitive $\left(\mathrm{Cd}^{\mathrm{S}}\right)$ derivatives were selected by replicate plating after culture on nutrient-agar plates overnight at $43^{\circ} \mathrm{C}$. Mitomycin $\mathrm{C}$ lysates of $\beta$-lactamase-producing and non-producing strains 13136 were again used to transfer cadmium resistance to these two strains, to produce a further two strains derived from the first pair, i.e., strains $1030^{\prime} \mathrm{Rf}^{\mathrm{R}}, \mathrm{Cd}^{\mathrm{R}}, \beta 1 \mathrm{la}-$ and $1030^{\prime} \mathrm{Rf}^{\mathrm{R}}, \mathrm{Cd}^{\mathrm{R}}, \beta 1 \mathrm{la}+$.

Plasmid DNA, extracted from these strains by a 
modification of the method of Birnboim and Doly (1979) in which lysostaphin replaced lysozyme, was separated by slab gel electrophoresis. When stained with ethidium bromide and seen by UV transillumination, the plasmid DNA from $\beta$ la + and $\beta$ la - strains had similar electrophoretic mobility. Both pairs of derivatives of strain 1030 were used in experiments to compare the susceptibility of $\beta \mathrm{la}+$ and $\beta \mathrm{la}-$ strains to lysozyme.

By use of Mitomycin-C lysates of recent clinical isolates of $S$. aureus, strains 37810,54353 and 778 , further derivatives of strain 1030 were constructed as abovestrains $1030 / 37810 \mathrm{Rf}^{\mathrm{R}}, \mathrm{Cd}^{\mathrm{S}}, \beta l \mathrm{a}+; 1030 / 54353 \mathrm{Rf}^{\mathrm{R}}, \mathrm{Cd}^{\mathrm{R}}$, $\beta \mathrm{la}+$; and $1030 / 778 \mathrm{Rf}^{\mathrm{R}}, \mathrm{Cd}^{\mathrm{s}}, \beta \mathrm{la}+$.

All the derivatives of strain 1030 appeared identical after growth on milk and mannitol salt agar and on BairdParker medium (1962) and had similar phage typing patterns (see the table).

\section{Susceptibility to lysozyme}

Stationary-phase cultures of all seven derivatives of $S$. aureus strain 1030 were prepared by seeding $10 \mathrm{ml}$ of nutrient broth with material from an overnight nutrientbroth culture to a concentration of $10^{6} \mathrm{staphylococci} / \mathrm{ml}$ and incubating at $37^{\circ} \mathrm{C}$ for $18 \mathrm{~h}$. To induce $\beta$-lactamase synthesis, methicillin or 2-2' carboxyphenyl-benzoyl-6aminopenicillanic acid (CBAP) was added at concentrations of $0 \cdot 1-5 \mathrm{mg} / \mathrm{L}$ before incubation. The cells from a $1 \mathrm{ml}$ sample of each overnight broth culture were washed twice and resuspended in $0 \cdot 1 \mathrm{M}$ Tris- $\mathrm{HCl}$ buffer, $p \mathrm{H} \mathrm{7.0.}$ To measure the effect of removing extra-cellular $\beta$ lactamase on the susceptibility of cocci to lysozyme, $\beta$ lactamase producing cells were incubated in $0 \cdot 2 \mathrm{M}$

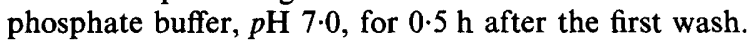
The influence of time of incubation in nutrient-broth cultures on the susceptibility of strain $1030 \mathrm{Rf}^{\mathrm{R}}, \mathrm{Cd}^{\mathrm{R}}, \beta \mathrm{Rla}-$ to lysozyme was also examined. For these experiments, $10-\mathrm{ml}$ volumes of warmed nutrient broth were seeded from a single overnight broth culture kept at $4{ }^{\circ} \mathrm{C}$ and incubated for intervals of up to $6 \mathrm{~h}$. The cells from each broth culture were then washed as described above.

The washed-cell suspensions were adjusted to the same optical density in a spectrophotometer (Pye Unicam SP 6) at $680 \mathrm{~nm}$, by adding $0 \cdot 1 \mathrm{M}$ Tris- $\mathrm{HCl}$ buffer, $p \mathrm{H} 7 \cdot 0$. Chicken egg-white lysozyme (Sigma Chemical Co., Poole, Dorset) was added in a range of concentrations from 50 to $1000 \mathrm{mg} / \mathrm{L}$ to Tris- $\mathrm{HCl}$ or phosphate buffer or saline, $0.01-0.2 \mathrm{M}$. In experiments to compare the susceptibility to lysozyme of derivatives of strain 1030 , lysozyme was prepared in $0.03 \mathrm{M}$ Tris- $\mathrm{HCl}$ buffer, $p \mathrm{H} 7.0$, at a concentration of $500 \mathrm{mg} / \mathrm{L}$. To limit differences in susceptibility due to small differences in growth rate, stationary-phase cultures were used in all these experiments. Tubes $(10 \times 1 \mathrm{~cm})$ containing $1 \mathrm{ml}$ of buffer or buffer plus lysozyme were seeded with the derivatives of strain 1030 to give a final concentration of viable organisms of $5 \times 10^{6} / \mathrm{ml}$. The tubes were then incubated unshaken for $1.5 \mathrm{~h}$ at $37^{\circ} \mathrm{C}$ in aerobic conditions.

\section{Viable bacterial counts}

Microbiological method. Tenfold dilutions of each livecell suspension were made in $0.1 \mathrm{M}$ buffer and $0.1 \mathrm{ml}$ volumes of each were spread on to two nutrient-agar plates which were incubated overnight at $37^{\circ} \mathrm{C}$. The mean viable counts were obtained by counting, with a colony counter, the colonies on plates carrying $30-300$ colonies.

Bioluminescence method. Cells were centrifuged at $800 \mathrm{~g}$ for $10 \mathrm{~min}$ to a pellet and $0.8 \mathrm{ml}$ of supernate removed by pipette before $0.2 \mathrm{ml}$ of trichloracetic acid $5 \% \mathrm{w} / \mathrm{v}$ with 4 mM EDTA was added to each tube to release intracellular ATP. After mixing, $10 \mu \mathrm{l}$ were removed and added to a cuvette containing $240 \mu \mathrm{l}$ of Tris-acetate buffer, $p \mathrm{H} \mathrm{7.75}$, with $2 \mathrm{~mm}$ EDTA and $50 \mu$ l of luciferase (LKB Wallace, Croydon, Surrey). The resulting light output was measured for $10 \mathrm{~s}$ in an LKB Wallace luminometer. An ATP standard was used to allow adjustment for differences in luciferase activity. There was less than $5 \%$ variation in luminometer values on repeated sampling from the same specimen.

Because lysozyme may cause aggregation of bacterial particles, particularly in solutions of low ionic strength (Golub et al., 1985), the viable counts were performed microbiologically and repeated by the luminometer method.

Table. Phage typing patterns (at RTD) of strains derived from S. aureus strain 1030

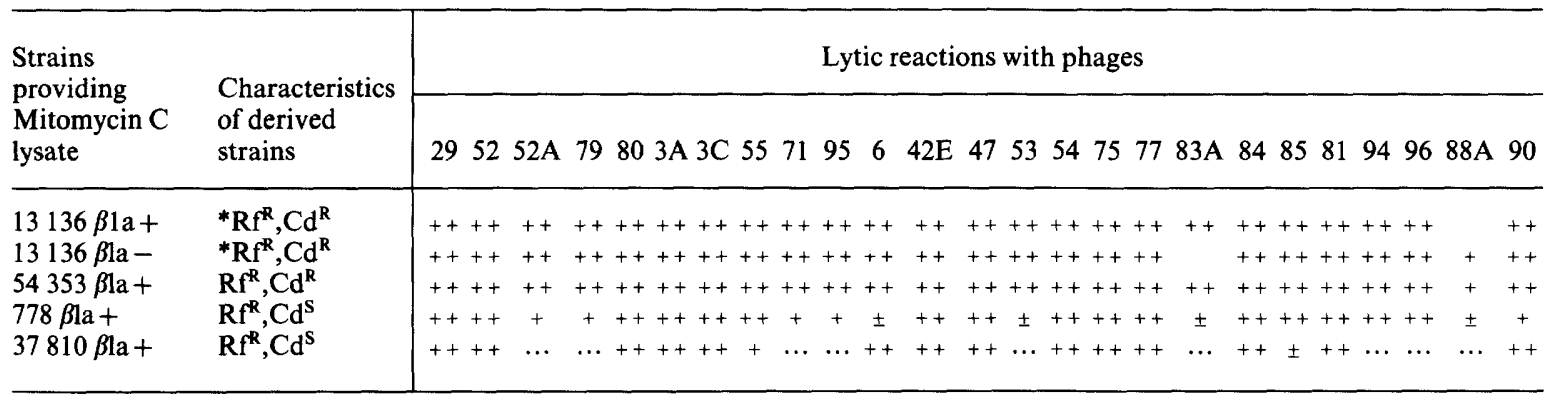

* 1st pair: The 2nd pair had an identical phage-typing pattern. $+_{+}=50$ plaques or more $;+=20-49$ plaques; $\pm=<20$ plaques. $\beta \mathrm{la}+=\beta$-lactamase producing $; \beta \mathrm{la}-=\beta$-lactamase non-producing $; \mathrm{Rf}=\mathrm{R}$ ifampicin $; \mathrm{Cd}=\mathrm{Cadmium} ; \mathrm{R}=\mathrm{Resistant} ; \mathrm{S}=\mathrm{Sensitive}$. 


\section{Percentage survival figures}

These were calculated from the formula:

$\underline{\text { Viable count in buffer }+ \text { lysozyme }} \times 100$

Viable count in buffer

\section{$\beta$-lactamase activity}

This was assayed by the iodometric method of Perret (1954).

\section{Results}

When the killing of $S$. aureus by lysozyme was investigated, reducing the molarity to below $0.04 \mathrm{M}$ in Tris- $\mathrm{HCl}$, phosphate buffers or saline increased the susceptibility of strain $1030 \mathrm{Rf}^{\mathrm{R}}, \mathrm{Cd}^{\mathrm{R}}, \beta \mathrm{la}-$, and cells prepared from broth cultures incubated aerobically were more susceptible in solutions of low molarity than those from broth cultures incubated anaerobically (fig. 1). The $\mathrm{pH}$ of a nutrient-broth culture of $S$. aureus strain 1030 grown aerobically for $18 \mathrm{~h}$ was 7.3 compared with 6.7 for a culture grown in anaerobic conditions. Increasing the concentration of lysozyme over the range 50 $1000 \mathrm{mg} / \mathrm{L}$ increased the killing of $S$. aureus strain $1030 \mathrm{Rf}^{\mathrm{R}}, \mathrm{Cd}^{\mathrm{R}}, \beta \mathrm{la}-$ (fig. 2). When the influence of the age of nutrient-broth cultures was studied (fig. 3 ), fewer cells from stationary-phase cultures incubated for $>6 \mathrm{~h}$ were killed than were cells from broth cultures incubated for $<2 \mathrm{~h}$.

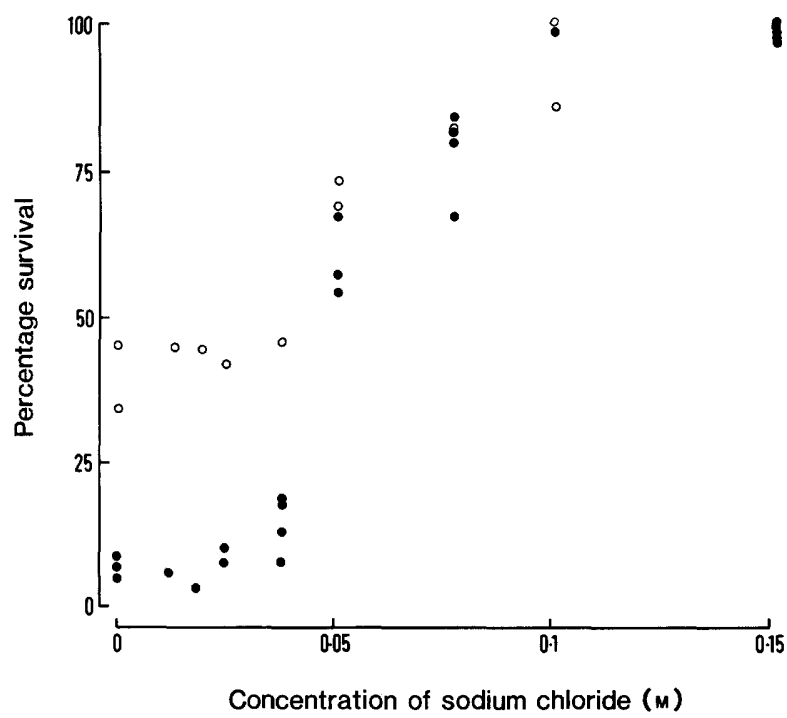

Fig. 1. The influence of sodium chloride concentration on survival of strain 1030 la - from aerobic and anaerobic stationary-phase cultures exposed to lysozyme $1000 \mathrm{mg} / \mathrm{L}$ for $1 \mathrm{~h}$ at $37^{\circ} \mathrm{C} ; \mathrm{O}=$ aerobic broth culture, $\mathrm{O}=$ anaerobic broth culture.

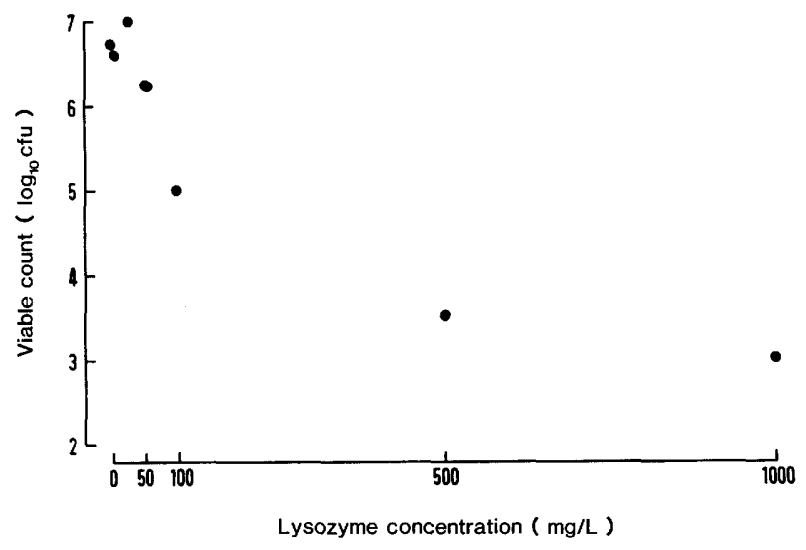

Fig. 2. The influence of lysozyme concentration in $0.02 \mathrm{M}$ phosphate buffer, $p \mathrm{H} 7$, acting for $3 \mathrm{~h}$ at $37^{\circ} \mathrm{C}$, on the viability of strain $1030 \mathrm{Bla}-$, prepared from aerobic 1 -h nutrient-broth cultures.

To compare the susceptibility of different strains to lysozyme, inocula were prepared from stationaryphase broth cultures grown aerobically. After incubation for $18 \mathrm{~h}$ at $37^{\circ} \mathrm{C}$, the $\beta$ la - derivatives of strain 1030 reached viable counts half as high again as those of the $\beta 1 \mathrm{l}+$ strains, the viable counts by either microbiological or bioluminescence methods being comparable. All the $\beta$ la + derivatives of strain 1030 were more resistant to lysozyme in the concentration range $100-500 \mathrm{mg} / \mathrm{L}$ than were the $\beta 1 \mathrm{a}-$ derivatives (fig. 4). When CBAP in concentrations of $0 \cdot 1-5 \mathrm{mg} / \mathrm{L}$ was used to induce an increase in $\beta$-lactamase synthesis in the 1030 and $1030^{\prime} \mathbf{R f}^{\mathrm{R}}, \mathrm{Cd}^{\mathrm{R}}, \beta$ la + derivatives, the cells produced 6-12 Perret units of $\beta$ lactamase $/ 10^{8}$ viable bacteria and viable counts of these preparations either did not fall or rose after incubation for $1.5 \mathrm{~h}$ at $37^{\circ} \mathrm{C}$ in the presence of lysozyme $500 \mathrm{mg} / \mathrm{L}$ in $0.03 \mathrm{M}$ Tris$\mathrm{HCl}$ buffer. The survival of the $\beta$ la - derivatives of strain 1030 in the presence of lysozyme did not differ from that of the $\mathrm{Rf}^{\mathrm{R}}$ derivative of strain $\mathbf{1 0 3 0}$ from which they were constructed, nor did addition of CBAP in concentrations of $0 \cdot 1-5 \mathrm{mg} / \mathrm{L}$ influence survival.

When concentrations of methicillin, from $0.06 \mathrm{mg} / \mathrm{L}$ to the MIC for both $\beta \mathrm{la}+$ and $\beta \mathrm{la}-$ derivatives of strain 1030 of $2 \mathrm{mg} / \mathrm{l}$, were added to broth cultures before incubation in lysozyme, the washed cells were more susceptible to lysozyme, despite the induction of $\beta$-lactamase synthesis in the $\beta$ la + strains by these concentrations of methicillin.

Incubation of the $\beta$ la + derivatives of strain 1030 in $0.2 \mathrm{M}$ phosphate buffer for $0.5 \mathrm{~h}$ at $37^{\circ} \mathrm{C}$ resulted in up to $50 \%$ reduction in the cell-associated $\beta$ lactamase (Coles and Gross, 1967) but did not 


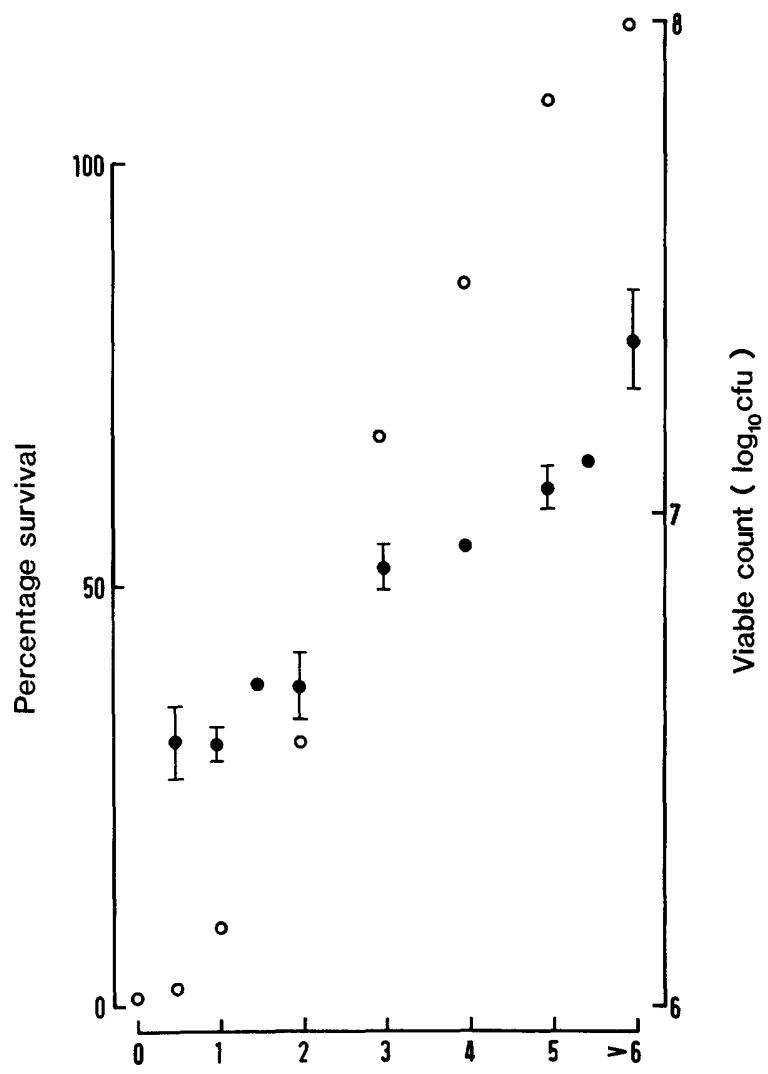

Time from inoculation of broth $(h)$

Fig. 3. The influence of the age of nutrient-broth cultures on the survival of strain $1030 \mathrm{Rf}^{\mathrm{R}}, \mathrm{Cd}^{\mathrm{R}}, \beta \mathrm{la}-$ exposed for $1.5 \mathrm{~h}$ at $37^{\circ} \mathrm{C}$ to lysozyme $300 \mathrm{mg} / \mathrm{L}$ in Tris- $\mathrm{HCl}$ buffer, $p \mathrm{H} \mathrm{7.0;}=$ mean survival and standard deviation (SD), $\mathrm{O}=$ viable count.

influence the susceptibility of these strains to lysozyme.

\section{Discussion}

Before penicillin was used in clinical trials in 1942 some strains of $S$. aureus were noted to be resistant to it (Segalove, 1947; Parker and Lapage, 1957; Altemeier et al., 1981). Since then, the percentage of diagnostic laboratory isolates of $S$. aureus producing $\beta$ lactamase has risen to more than 80 . In early studies, $\beta$-lactamase-producing strains of $S$. aureus were acquired by patients and nursing staff not exposed to therapeutic penicillin (Barber and Rozwadowska-Dowzenko, 1948; Rountree and Thomson, 1949), possibly as a result of exposure to environmental penicillin (Gould, $1958)$, but the number of $\beta$-lactamase-producing strains also rose in the community outside the hospital. The majority of clinical isolates of $S$. aureus are now resistant to penicillin, yet resistance to other antibiotics is far less common despite the widespread use of tetracyclines, erythromycin and other antibiotics with anti-staphylococcal activity. Methicillin-resistant strains produce large amounts of $\beta$ lactamase (Richmond et al., 1964), despite being penicillin-resistant at $30^{\circ} \mathrm{C}$, the temperature of the anterior nares, the carrier site for $S$. aureus (O'Grady and Wittstadt, 1963; Polakoff et al., 1967).

Plasmid-mediated $\beta$-lactamase synthesis in $S$. aureus may be lost in vitro on non-selective media but since 1966 there have been several reports of chromosomally mediated $\beta$-lactamase synthesis in $S$. aureus (Asheshov, 1966; Sweeney and Cohen, 1968 ) and chromosomal $\beta$-lactamase synthesis may be becoming more common (Townsend et al., 1985).

The concentration of sodium chloride in nasal mucus is not known, but is probably similar to that of tracheo-bronchial mucus, which has been reported from animal studies to be $<0.02 \mathrm{M}$ (Boyd $e t$

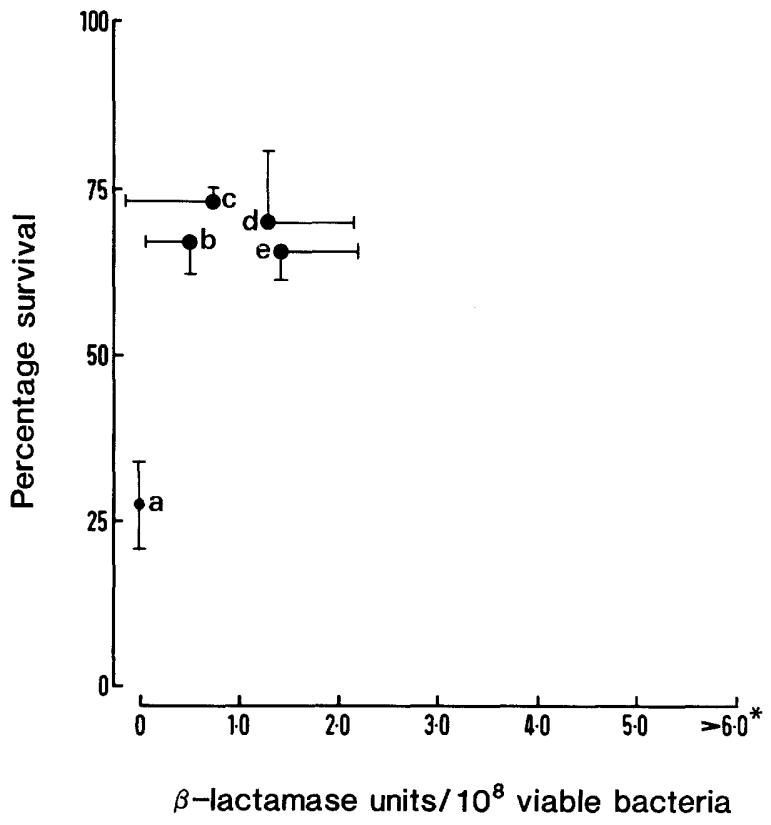

Fig. 4. The influence of $\beta$-lactamase production on the survival of derivatives of strain 1030 incubated for $1.5 \mathrm{~h}$ at $37^{\circ} \mathrm{C}$ in $0.03 \mathrm{M}$ Tris- $\mathrm{HCl}$ buffer, $\mathrm{pH} 7$, containing lysozyme $500 \mathrm{mg} / \mathrm{L} . \quad=$ mean and $\mathrm{SD} ; \mathrm{a}=$ strain $1030 \mathrm{Rf}^{\mathrm{R}}, \mathrm{Cd}^{\mathrm{R}}, \beta \mathrm{la}-(6) ; \mathrm{b}=$ strain $1030 / 778$ $\mathrm{Rf}^{\mathrm{R}}, \mathrm{Cd}^{\mathrm{R}}, \beta \mathrm{la}+(3) ; \mathrm{c}=$ strain $1030 / 37810 \mathrm{Rf}^{\mathrm{R}}, \mathrm{Cd}^{\mathrm{R}}, \beta \mathrm{la}+(3)$; $\mathrm{d}=$ strains 1030 and $1030^{\prime} \mathrm{Rf}^{\mathrm{R}}, \mathrm{Cd}^{\mathrm{R}}, \beta \mathrm{a}+(6) ; \mathrm{e}=$ strain $1030 /$ $54353 \mathrm{Rf}^{\mathrm{R}}, \mathrm{Cd}^{\mathrm{R}}, \beta \mathrm{la}+(3) ; \mathrm{f}=$ strains 1030 and $1030^{\prime} \mathrm{Rf}^{\mathrm{R}}, \mathrm{Cd}^{\mathrm{R}}$, $\beta$ la $+(6)$ after induction of $\beta$-lactamase synthesis with CBAP;

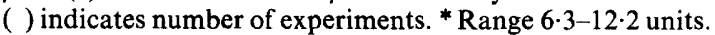


al., 1944). The dilution of tears by nasal mucus could produce lysozyme concentrations of 100 $500 \mathrm{mg} / \mathrm{L}$ with a molarity of $<0.04 \mathrm{M}$ sodium chloride. The lysis of the cell wall of Micrococcus lysodeikticus (Davies et al., 1967), the aggregation of streptococci (Laible and Germaine, 1982; Golub et al., 1985) and the killing of Streptococcus sanguis (Laible and Germaine, 1985) by lysozyme depend upon a reduction in ionic strength. The present study has shown that lysozyme kills $S$. aureus in conditions which could result from dilution of tears by nasal mucus. The mechanism for this killing may be through lysis of staphylococci following the activation of cell wall autolysins by lysozyme, after adsorption of lysozyme to the bacterial cell wall.

$S$. aureus strain $1030 \mathrm{Rf}^{\mathrm{R}}, \mathrm{Cd}^{\mathrm{R}}, \beta \mathrm{la}$ - was less susceptible to lysozyme when grown in broth incubated anaerobically rather than aerobically. Small differences in $p \mathrm{H}$ influence the alanyl ester content of cell-wall teichoic acids (Rogers et al., 1980 ) and may thereby alter the susceptibility of $S$. aureus to lysozyme through an alteration in polymer charge.

The $\beta$-lactamase-producing derivatives of $S$. aureus strain 1030 were more resistant to lysozyme than non-producing derivatives. However, removal of the extracellular $\beta$ lactamase by incubation in $0 \cdot 2 \mathrm{M}$ phosphate buffer did not increase the susceptibility of strains to lysozyme, suggesting that the membrane-bound $\beta$ lactamase may be responsible for inhibiting lysozyme killing, perhaps by inhibiting the binding of lysozyme to the cytoplasmic membrane or to lipoteichoic acids, which are important in stabilising cell wall autolytic enzymes.

$\beta$-Lactam antibiotics at sub-inhibitory concentrations enhance the lysis of $S$. aureus by lysozyme

\section{REFERENCES}

Altemeier W A, Lewis S, Brachett K 1981 The Versatile Staphylococcus. In: Macdonald A, Smith D (eds) The Staphylococci. Pergamon Press, Oxford, pp 125-148.

Ambler R P, Meadway R J 1969 Chemical structure of bacterial penicillinases. Nature 222: 24-26.

Asheshov E H 1966 Loss of antibiotic resistance in Staphylococcus aureus resulting from growth at high temperature. Journal of General Microbiology 42: 403-410.

Baird-Parker A C 1962 An improved diagnostic and selective medium for isolating coagulase positive staphylococci. Journal of Applied Bacteriology 25: 12-19.

Barber M, Rozwadowska-Dowzenko M 1948 Infection by penicillin-resistant staphylococci. Lancet 2: 641-644.

Birnboim H C, Doly J 1979 A rapid alkaline extraction procedure for screening recombinant plasmid DNA. Nucleic Acid Research 7: 1513-1523.

Boyd E M, Jackson S, MacLachlan M, Palmer B, Stevens M, Whittaker J 1944 The lipid, sodium, chloride and nitrogen
(Warren and Gray, 1965; Ginsburg et al., 1982) and, in this study, methicillin at sub-inhibitory concentrations enhanced the killing of $S$. aureus strain 1030 by lysozyme. This effect may be due to alterations in cell-wall structure (Tomasz, 1979). CBAP, which at concentrations of $<5 \mathrm{mg} / \mathrm{L}$ does not damage the cell wall of $S$. aureus (Leggate and Holms, 1968), did not influence the susceptibility to lysozyme of the $\beta$ la - derivatives of strain 1030 . Growth of the $\beta$ la + strains in the presence of CBAP at concentrations up to $5 \mathrm{mg} / \mathrm{L}$, however, resulted in increased resistance of those strains to lysozyme, perhaps as a result of the induction of $\beta$ lactamase synthesis, in the absence of cell wall damage.

Penicillin therapy, by selecting for $\beta$-lactamase production, may have selected strains of $S$. aureus with increased resistance to host-derived cationic proteins. Lysozyme may help to maintain the $\beta$ lactamase-producing strains of $S$. aureus that have been selected at the carrier site by antibiotic therapy. Apart from lysozyme, other cationic proteins may select for $\beta$-lactamase synthesis by $S$. aureus. Neutrophil granules contain several cationic proteins that have potent bactericidal activity (Olsson et al., 1978). Neutrophils from patients with chronic granulomatous disease will kill $S$. aureus, despite a defect in the oxygen-dependent killing system (Elsbach and Weiss, 1981; Quie et al., 1967) and neutrophils will also kill $S$. aureus in anaerobic conditions (Mandell, 1974). The exposure of $S$. aureus on the mucosa of the anterior nares to lysozyme will vary with time and between individuals and may provide a less potent selection pressure than the granular cationic proteins present in an inflammatory exudate (Noble, 1977).

content of the respiratory tract fluid of normal animals. Journal of Biological Chemistry 153: 435-438.

Bretz U, Baggiolini M 1974 Biochemical and morphological characterization of azurophil and specific granules of human neutrophilic polymorphonuclear leukocytes. Journal of Cell Biology 63: 251-269.

Brumfitt W, Wardlaw A C, Park J T 1958 Development of lysozyme resistance in Micrococcus lysodeikticus and its association with an increased O-acetyl content of the cell wall. Nature 181 : 1783-1784.

Coles N W, Gross R 1967 Liberation of surface-located penicillinase from Staphylococcus aureus. Biochemical Journal 102: 742-747.

Davies R C, Neuberger A, Wilson B M 1969 The dependence of lysozyme activity on $p \mathrm{H}$ and ionic strength. Biochimica et Biophysica Acta 178: 294-305.

Dyke K G H, Parker M T, Richmond M H 1970 Penicillinase production and metal-ion resistance in Staphylococcus aureus cultures isolated from hospital patients. Journal of Medical Microbiology 3: 125-136. 
Elsbach P, Weiss J 1981 Oxygen-independent bactericidal systems of polymorphonuclear leukocytes. Advances in Inflammation Research 2: 95-113.

Ginsburg I, Lahav M, Bergner-Rabinowitz S, Ferne M 1982 Effects of antibiotics on the lysis of staphylococci and streptococci by leucocyte factors, on the production of cellular and extra-cellular factors by streptococci, and on the solubilization of cell-sensitizing agents from gramnegative rods. In : Eickenberg $\mathrm{H}-\mathrm{U}$ et al. (eds) The influence of antibiotics on the host-parasite relationship. SpringerVerlag, Berlin, pp 219-227.

Golub E E, Cheruka J, Boosz B, Davis C, Malamud D 1985 A comparison of bacterial aggregation induced by saliva, lysozyme and zinc. Infection and Immunity 48: 204-210.

Gould J C 1958 Environmental penicillin and penicillin-resistant Staphylococcus aureus. Lancet 1 : 489-493.

Iacono V J, MacKay B J, Dirienzo S, Pollock J J 1980 Selective antibacterial properties of lysozyme for oral microorganisms. Infection and Immunity 29: 623-632.

Jevons M P 1961 "Celbenin" resistant staphylococci. British Medical Journal 1: 124-125.

Kern R A, Kingkade M J, Kern S F, Behrens O K 1951 Characterization of the action of lysozyme on Staphylococcus aureus and Micrococcus lysodeikticus. Journal of Bacteriology 61 : 171-178.

Lacey R W 1971 Transfer of tetracycline-resistance between strains of Staphylococcus aureus in mixed cultures. Journal of General Microbiology 69: 229-237.

Leffell M S, Spitznagel J K 1972 Association of lactoferrin with lysozyme in granules of human polymorphonuclear leukocytes. Infection and Immunity 6: 761-765.

Laible N J, Germaine G R 1982 Adsorption of lysozyme from human whole saliva by Streptococcus sanguis 903 and other oral microorganisms. Infection and Immunity 36: 148-159.

Laible N J, Germaine G R 1985 Bactericidal activity of human lysozyme, muramidase-inactive lysozyme and cationic polypeptides against Streptococcus sanguis and Streptococcus faecalis: inhibition by chitin oligosaccharides. Infection and Immunity 48: 720-728.

Leggate J, Holms W H 1968 Gratuitous synthesis of $\beta$-lactamase in Staphylococcus aureus. Journal of Bacteriology 96: 21102117.

Mandell G L 1974 Bactericidal activity of aerobic and anaerobic polymorphonuclear neutrophils. Infection and Immunity 9: 337-341.

Mandelstam M H, Strominger J L 1961 On the structure of the cell wall of Staphylococcus aureus (Copenhagen). Biochemical and Biophysical Research Communications 5: 466-477.

Millar M, Lacey R W 1984 Possible selection of $\beta$-lactamaseproducing Staphylococcus aureus by lysozyme. Lancet 2 : 987.

Mitchell P, Moyle J 1957 Autolytic release and osmotic properties of "protoplasts" from Staphylococcus aureus. Journal of General Microbiology 16: 184-94.

Morse S I 1965 Biological attributes of staphylococcal cell walls. Annals of the New York Academy of Sciences 128: 191213.

Neilsen J B K, Lampen J O 1982 Membrane-bound penicillinases in gram-positive bacteria. Journal of Biological Chemistry 257: 4490-5.
Noble W C 1977 Variation in the prevalence of antibiotic resistance of Staphylococcus aureus from human skin and nares. Journal of General Microbiology 98: 125-132.

Novick R 1967 Properties of a cryptic high-frequency transducing phage in Staphylococcus aureus. Virology 33: 155-166.

O'Grady F, Wittstadt F B 1963 Nasal carriage of Staphylococcus pyogenes. II. Bacterial ecology of the nose. American Journal of Hygiene 77 : 187-194.

Olsson J, Odeberg H, Weiss J, Elsbach P 1978 Bactericidal cationic proteins of human granulocytes. In: Havemann K., Janoff A. (eds) Neutral proteases of human polymorphonuclear leucocytes: biochemistry, physiology and clinical significance. Urban and Schwarzenberg, Baltimore, pp 18-32.

Parker M T, Lapage S P 1957 Penicillinase production by Staphylococcus aureus strains from outbreaks of food poisoning. Journal of Clinical Pathology 10 : 313-317.

Perret C J 1954 Iodometric assay of penicillinase. Nature: 174 1012-1013.

Polakoff S, Richards I D G, Parker M T, Lidwell O M 1967 Nasal and skin carriage of Staphylococcus aureus by patients undergoing surgical operation. Journal of Hygiene 65 : 559566.

Quie P G, White J G, Holmes B, Good R A 1967 In vitro bactericidal capacity of human polymorphonuclear leucocytes: diminished activity in chronic granulomatous disease of childhood. Journal of Clinical Investigation 46: 668-679.

Richmond M H, Parker M T, Jevons M P, John M 1964 High penicillinase production correlated with multiple antibiotic resistance in Staphylococcus aureus. Lancet 1: 293-296.

Richmond M H 1975 B-lactamase (Staphylococcus aureus). Methods in Enzymology XLIII: 664-72.

Rogers H J, Perkins H R, Ward J B 1980 Microbial cell walls and membranes. Chapman and Hall, London.

Rountree P M, Thomson E F 1949 Incidence of penicillinresistant and streptomycin-resistant staphylococci in a hospital. Lancet 2: 501-504.

Segalove M 1947 The effect of penicillin on growth and toxin production by enterotoxic staphylococci. Journal of Infectious Diseases 81 : 228-43.

Sweeney H M, Cohen S 1968 Wild-type strain of Staphylococcus aureus containing two genetic linkage groups for penicillinase production. Journal of Bacteriology 96: 920-924.

Thorne K J I, Oliver R C, Barrett A J 1976 Lysis and killing of bacteria by lysosomal proteinases. Infection and Immunity 14: $555-563$.

Tomasz A 1979 The mechanism of the irreversible antimicrobial effects of penicillins: how the $\beta$-lactam antibiotics kill and lyse bacteria. Annual Reviews of Microbiology 33: 113-137.

Townsend D E, Ashdown N, Grubb W B 1985 Evolution of Australian isolates of methicillin-resistant Staphylococcus aureus. A problem of plasmid incompatibility? Journal of Medical Microbiology 20: 49-61.

Warren G H, Gray J 1965 Effect of sublethal concentrations of penicillins on the lysis of bacteria by lysozyme and trypsin. Proceedings of the Society for Experimental Biology and Medicine 120: 504-511.

Wecke J, Lahav M, Ginsburg I, Giesbrecht P 1982 Cell wall degradation of Staphylococcus aureus by lysozyme. Archives of Microbiology 131 : 116-123. 